\title{
Limited dispersal and an unexpected aggression pattern in a native supercolonial ant
}

\author{
Sanja M. Hakala ${ }^{1,2}$ (D) | Mats Ittonen ${ }^{1,2,3}$ (D) | Perttu Seppä ${ }^{1,2}$ | Heikki Helanterä ${ }^{1,2,4}$
}

\author{
${ }^{1}$ Centre of Excellence in Biological \\ Interactions, Organismal and Evolutionary \\ Biology Research Programme, Faculty of \\ Biological and Environmental Sciences, \\ University of Helsinki, Helsinki, Finland \\ ${ }^{2}$ Tvärminne Zoological Station, University of \\ Helsinki, Hanko, Finland \\ ${ }^{3}$ Department of Zoology, Stockholm \\ University, Stockholm, Sweden \\ ${ }^{4}$ Ecology and Genetics Research Unit, \\ University of Oulu, Oulu, Finland

\section{Correspondence} \\ Mats Ittonen, Department of Zoology, \\ Stockholm University, 10691 Stockholm, \\ Sweden. \\ Email: mats.ittonen@zoologi.su.se \\ Funding information \\ Societas Biologica Fennica Vanamo; \\ Academy of Finland, Grant/Award Number: \\ 135970, 140990, 251337 and 284666; \\ Helsingin hyönteistieteellinen yhdistys; \\ Suomen Kulttuurirahasto; Societas \\ Pro Fauna et Flora Fennica; Suomen \\ hyönteistieteellinen seura; Betty Väänäsen \\ säätiö; Vetenskapsrådet; Bolin Centre for \\ Climate Research; Koneen Säätiö; Alfred \\ Kordelinin Säätiö
}

\begin{abstract}
Understanding how social groups function requires studies on how individuals move across the landscape and interact with each other. Ant supercolonies are extreme cooperative units that may consist of thousands of interconnected nests, and their individuals cooperate over large spatial scales. However, the inner structure of suggested supercolonial (or unicolonial) societies has rarely been extensively studied using both genetic and behavioral analyses. We describe a dense supercolony-like aggregation of more than 1,300 nests of the ant Formica (Coptoformica) pressilabris. We performed aggression assays and found that, while aggression levels were generally low, there was some aggression within the assumed supercolony. The occurrence of aggression increased with distance from the focal nest, in accordance with the genetically viscous population structure we observe by using 10 DNA microsatellite markers. However, the aggressive interactions do not follow any clear pattern that would allow specifying colony borders within the area. The genetic data indicate limited gene flow within and away from the supercolony. Our results show that a Formica supercolony is not necessarily a single unit but can be a more fluid mosaic of aggressive and amicable interactions instead, highlighting the need to study internest interactions in detail when describing supercolonies.
\end{abstract}

\section{KEYWORDS}

aggression assay, dispersal, Hymenoptera, nestmate recognition, polydomy, polygyny

\section{1 | INTRODUCTION}

Cooperation in social groups can be favored when interacting individuals are related, or otherwise share alleles for cooperative behavior (Hamilton, 1964a; 1964b). Indeed, highly cooperative groups across all domains of life are usually family groups, where relatedness among group members is high (Bourke, 2011). However, the benefits of cooperation may be canceled out if relatives simultaneously compete with each other locally. The balance between kin-selected cooperation and harmful competition with relatives is delicate, and especially the roles of spatial patterns and dispersal have received considerable attention (e.g., Kümmerli, Gardner, West, \& Griffin, 2009; Platt \& Bever, 2009; Queller, 1992; Taylor, 1992; West, Pen, $\&$ Griffin, 2002). However, the spatial scales of cooperation and competition remain understudied in natural populations. They can be especially difficult to interpret in genetically viscous populations,

Hakala and Ittonen contributed equally to the article.

This is an open access article under the terms of the Creative Commons Attribution License, which permits use, distribution and reproduction in any medium, provided the original work is properly cited.

(c) 2020 The Authors. Ecology and Evolution published by John Wiley \& Sons Ltd. 
where limited dispersal leads to relatives aggregating together, leading to both increased kin competition and more possibilities for cooperation among relatives (Queller, 1992; Taylor, 1992). Understanding the relevant spatial scales of cooperation and competition requires knowledge on how individuals move across landscapes and interact with each other.

Ants are a good example of obligate eusociality, where a reproductive caste depends on help from a sterile worker caste (Crespi \& Yanega, 1995). In several ant species, colony structures have grown beyond the ancestral simple family unit, from which eusociality originally evolved (Boomsma, 2009). In many ant taxa, dispersal is limited, and new nests are formed by budding from a parent nest, instead of long-range dispersal by flying sexual offspring (Cronin, Molet, Doums, Monnin, \& Peeters, 2013). In some of these taxa, this leads to the formation of polydomous colonies where several nests are interconnected and work together as a single colony (Debout, Schatz, Elias, \& McKey, 2007). Further, polydomy is often associated with polygyny (multiple reproducing queens per colony) and the colonies can grow extremely large and have extremely high numbers of queens. This leads to colony members being unrelated at the local scale (Boomsma, Huszár, \& Pedersen, 2014; Helanterä, Strassmann, Carrillo, \& Queller, 2009), which challenges traditional definitions of colonies as kin-selected cooperative units. Very large polydomous and polygynous colonies are often called supercolonies (Helanterä et al., 2009). In a supercolony, the cooperative colony spans larger spatial scales than a single individual can cross (Helanterä et al., 2009; Pedersen, Krieger, Vogel, Giraud, \& Keller, 2006), but individuals still recognize and treat each other as members of the same colony when brought together (Moffett, 2012). As an extreme example, a genetically homogenous single colony of the Argentine ant Linepithema humile has spread over the whole globe, but individuals living on different continents still behaved as one colony in behavioral experiments (Brandt, Wilgenburg, \& Tsutsui, 2009; Holway, Suarez, \& Case, 1998; van Wilgenburg, Torres, \& Tsutsui, 2010).

Although the existence of supercolonies is something of an evolutionary paradox due to low relatedness within these cooperative units (Giraud, Pedersen, \& Keller, 2002), they are ecologically very dominant (Human \& Gordon, 1996). This has led to many supercolonial ant species becoming harmful invasive pests (GISD, 2019), the best-studied example being the above-mentioned Argentine ant (Giraud et al., 2002; Tsutsui \& Case, 2001). It forms massive supercolonies, especially in its invasive ranges, where it has been able to spread without much competition (Tsutsui \& Suarez, 2003; Wetterer, Wild, Suarez, Roura-Pscual, \& Espadaler, 2009), and smaller supercolonies in its native ranges (Pedersen et al., 2006; Vogel, Pedersen, D'Ettorre, Lehmann, \& Keller, 2009). Similarly, polygynous and polydomous colonies of the fire ant (Solenopsis in victa) reach very large sizes and densities, and are ecologically dominant in their invasive range (Ascunce et al., 2011; Ross, Vargo, \& Keller, 1996). Supercoloniality has evolved independently in several other taxa across the ant phylogeny, some of which are not invasive (Helanterä et al., 2009). Studying the spatial scale and inner social organization of supercolonial societies in all of these taxa would give a fuller understanding of the evolution and maintenance of such high levels of cooperation (Robinson, 2014).

The ability of ant individuals to distinguish between group members and outsiders makes it possible to define the borders of supercolonies (Moffett, 2012). Individuals recognize their colonymates using olfactory cues such as cuticular hydrocarbons that can be both genetically determined and acquired from the environment and food (Ginzel \& Blomquist, 2016; Howard, 1993; Vander Meer \& Morel, 1998). As ants usually behave aggressively toward intruders, aggression assays are commonly used to study nest- and colonymate recognition, and provide a simple way to infer colony boundaries, and thus also spatial scales of potential cooperation (Roulston, Buczkowski, \& Silverman, 2003). Even the largest supercolonies lack internest aggression within the colony, while they do behave aggressively toward other conspecific (super)colonies (Giraud et al., 2002; Holway et al., 1998; Thomas, Payne-Makrisâ, Suarez, Tsutsui, \& Holway, 2007; Tsutsui, Suarez, Holway, \& Case, 2000). However, not all supercolonies and supercolonial species reported in the literature have been rigorously tested for internest aggression or resource sharing (Hoffmann, 2014), but instead some of them have been described as supercolonial based only on genetic data and the spatial organization of nests (Helanterä et al., 2009).

Formica ants offer excellent possibilities for studying spatial scales of cooperation and the evolution of social organization, as this genus has large variation in social organization, from simple family units all the way to very large supercolonies (Ellis \& Robinson, 2014; Helanterä et al., 2009; Rosengren \& Pamilo, 1983; Rosengren, Sundström, \& Fortelius, 1993). The largest reported example is a 45,000 nest supercolony of Formica yessensis (Higashi \& Yamauchi, 1979), while supercolonies in other Formica species range from tens to a few thousands of nests (Markó, Czekes, Eros, Csata, \& Szász-Len, 2012). In some cases, populations of the same species vary in their social structure, and, for example, in Formica exsecta, it seems that polygynous, polydomous, and supercolonial populations can arise from monogynous background populations (Seppä, Gyllenstrand, Corander, \& Pamilo, 2004). Formica populations tend to be genetically viscous; that is, spatially close nests are more closely related than spatially distant ones, which is especially true in polygynous species and populations where young queens are often philopatric (Chapuisat, Goudet, \& Keller, 1997; Rosengren et al., 1993; Sundström, Seppä, \& Pamilo, 2005). While patterns of genetic variation in supercolonial Formica ants have been studied in detail before (Chapuisat et al., 1997; Elias, Rosengren, \& Sundström, 2005; Holzer, Keller, \& Chapuisat, 2009; Seppä et al., 2004; Seppä, Johansson, Gyllenstrand, Pálsson, \& Pamilo, 2012; Sundström et al., 2005), these studies have rarely combined genetic data with behavioral experiments to assess the scale of cooperation, or potential for it. Recognition behavior and internest aggression has been tested in some species (Chapuisat, Bernasconi, Hoehn, \& Reuter, 2005; Holzer, Chapuisat, Kremer, Finet, \& Keller, 2006; KidokoroKobayashi et al., 2012; Martin, Helanterä, Kiss, Lee, \& Drijfhout, 2009; Pohl, Ziemen, \& Witte, 2018), but overall the behavioral structure of highly polydomous Formica colonies remains understudied.

We investigate the nature and spatial scale of supercoloniality in the highly polydomous ant Formica pressilabris using behavioral 
assays and DNA microsatellite data. We test the hypothesis that behavioral colony borders correspond to the spatial and genetic structuring of a large nest aggregation, which is an underlying assumption of many previous studies. Based on this hypothesis, we expect nests at a densely populated F. pressilabris site to either belong to one supercolony without internest aggression, or possible internest aggression to occur between spatially or genetically distinct supercolonies competing with each other. We use genetic data to infer dispersal patterns within and outside of this supercolonial nest aggregation. As supercoloniality has previously been linked to limited dispersal, our hypothesis is that the dense nest aggregation is genetically somewhat separated from three other closely located study sites, and competition thus largely local. Additionally, we expect the philopatry of daughter queens to lead to genetic viscosity within our supercolonial site.

\section{MATERIAL AND METHODS}

\subsection{Study species and sites}

Formica (Coptoformica) pressilabris (Figure 1) is a mound-building ant that lives on meadows and banks, builds nests of grass, and tends aphids for its main energy supply (Schultz \& Seifert, 2007; Seifert, 2000) It founds new nests via temporary social parasitism with other Formica (Serviformica) species as its host, or via budding from a parent nest (Czechowski, 1975; Kutter, 1969). While monogynous colonies have been reported, secondary polygyny, where daughter queens stay in their natal nests, is common. A single nest can have hundreds of queens and grow up to over one meter in diameter, which is exceptionally large for such a small Formica species (Collingwood, 1979; Czechowski, 1975; Pamilo \& Rosengren, 1984; Rosengren et al., 1993; Seifert, 2000). Colonies are also commonly polydomous with several interconnected nests and no aggression between nests (Collingwood, 1979; Czechowski, 1975; Seifert, 2000). Nest turnover is high in polydomous colonies; that is, new satellite nests are built regularly while old ones are abandoned (Bönsel, 2007).

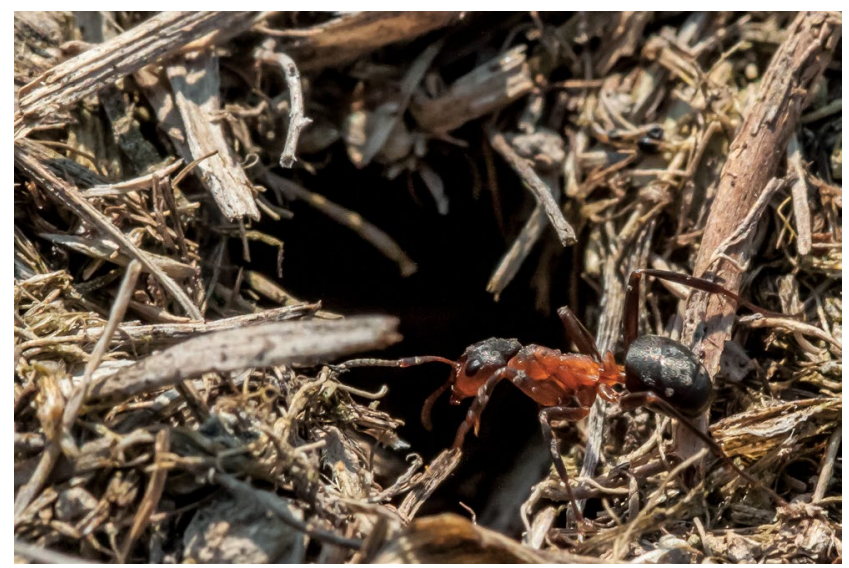

FIGURE 1 The study species, Formica pressilabris
We sampled a F. pressilabris population in Southern Finland in 2016. The sampled area consists of one 9-ha abandoned field (Särkkilen) with a large continuous nest aggregation (hereafter referred to as the supercolony site), and three closely located smaller sites with smaller nest aggregations (Storgård, Lillgård, Storsand; Figure 2). The three largest sites are former cropland, set aside for years or decades and now vegetated mainly by tall grass as well as some bushes and young trees. The smallest site is an edge area between cropland and forest. To assess whether the colonization potential of the area was fully used, we also extensively, although not exhaustively, searched for nests in other suitable habitats inside a $1 \mathrm{~km}$ radius from the supercolony site, but did not find additional colonies. Relatedness among worker nestmates estimated in a part of the supercolony site $(r=.21 \pm .02$, determined with DNA microsatellites, Schultner, Gardner, Karhunen, \& Helanterä, 2014) indicates polygyny and/or polydomy, that is, movement of individuals among nests. In our sampling, we counted nest mounds separated by more than $20 \mathrm{~cm}$ as separate nests. For our behavioral experiments and genetic analysis, we identified four spatially distinct parts of the supercolony site, with a clear gap between parts II and III (Figure 2) and less clear gaps between the parts I and II, and III and IV, making the latter two divisions somewhat arbitrary (Figure 2). We calculated nest densities first for the whole supercolony site and then separately for each of the four parts on it, as well as for the three smaller sites, using QGIS 3.4.1 (QGIS Development Team, 2018). For the whole supercolony site, we used the complete open area of the field for the calculation, whereas for its four parts and the three separate fields we used the areas of the polygons obtained by drawing straight lines between the outermost nests belonging to the respective areas. The age of the study population is not known, but the supercolony site has not been cultivated since the 1970s (landowner P. Forsbom, personal communication). Thus, the F. pressilabris population may have occupied the site for up to five decades.

\section{2 | Behavioral assays}

We performed behavioral assays in order to determine whether workers from the supercolony site behave differently toward their nestmates, conspecifics from other close and distant nests at the same site, conspecifics from other sites, and allospecific ants. These treatments are hereafter referred to as control, neighbor, distant, outside, and allospecific, respectively. We expected no aggression within the supercolony site, and that if any aggression were observed, it would occur across the nest-free gap in the middle of the site (Figure 2), as the gap may form a barrier between two separate supercolonies. We expected more aggression toward individuals from other sites than toward individuals from within the supercolony site. The closely related species $F$. exsecta should always be faced with aggression, as F. pressilabris has previously been shown to behave very aggressively against it (Czechowski, 1971).

We collected workers from 16 F. pressilabris nests at the supercolony site, covering all four parts (Figure 2). Additionally, we collected F. 

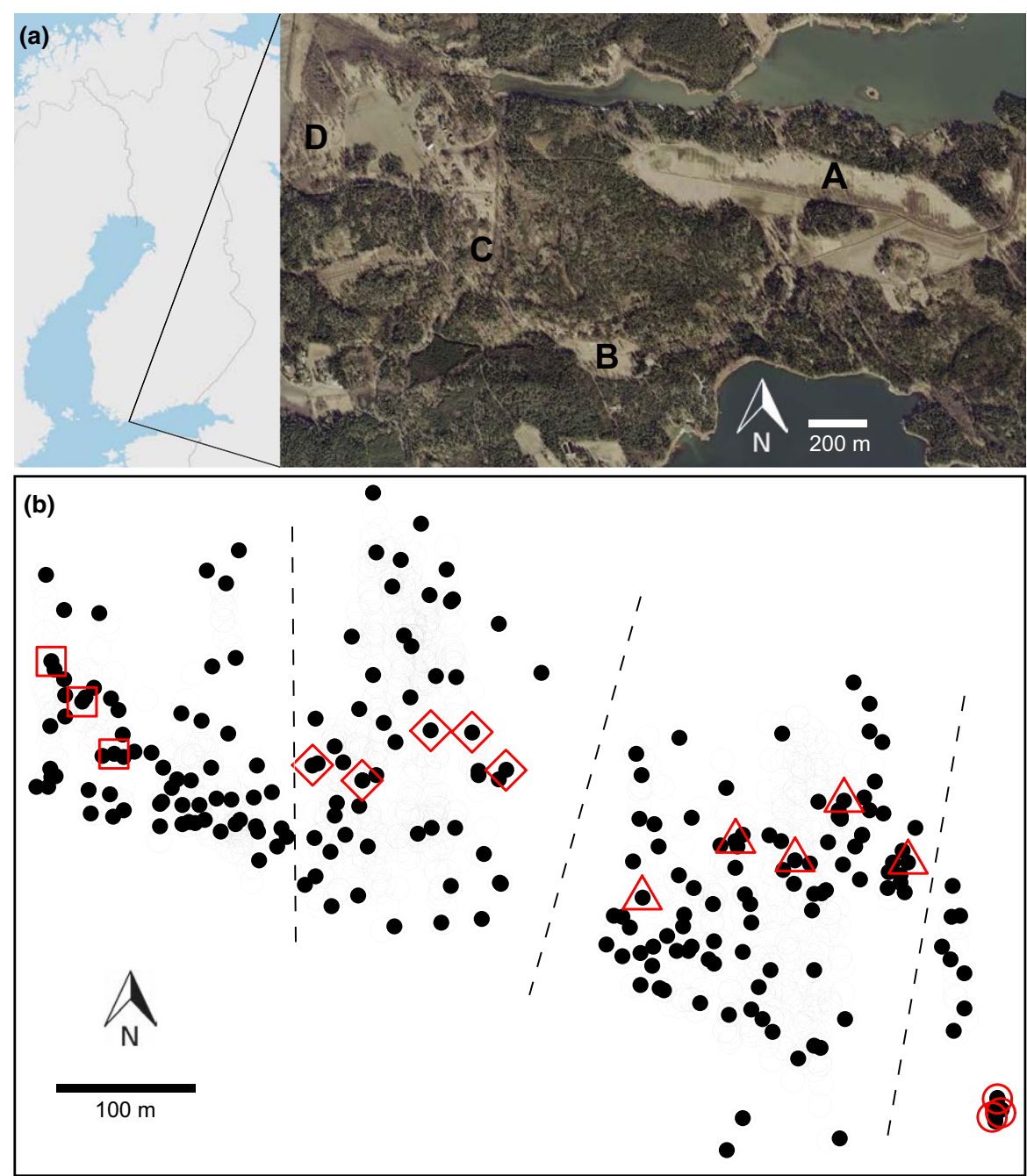

FIGURE 2 (a) The study area. The sampled subpopulations are indicated with letters. A: The supercolony field Särkkilen; B-D: The smaller fields, Storsand, Lillgård, and Storgård, respectively. (b) Locations of the nests on the supercolony field (circles). The nests used for genotyping are marked with filled circles, and the nests used for the behavioral experiments with red symbols. The red squares, diamonds, triangles, and circles represent parts I, II, III, and IV, respectively (see text). There are relatively large nest-free gaps between the parts (70 $\mathrm{m}$ between II and III; $31 \mathrm{~m}$ between III and IV), except for parts I and II, which are separated by a narrower (18 $\mathrm{m}$ ) area dominated by several Formica exsecta nests. Dashed lines mark the borders between the parts. The red circles in part IV have been slightly moved apart in order to show them all. Aerial image from National Land Survey of Finland NLS Orthophotos database 04/2019 (CC BY-SA 4.0) pressilabris workers from four nests at one of the smaller study sites, and one nest at another location approximately $30 \mathrm{~km} \mathrm{SW}$ of the study population (Tvärminne). We also sampled two F. exsecta nests from the main study area and one from Tvärminne. We collected 2-5 $L$ of nest material and a minimum of 300 workers from each nest on June 29 and 30. In the laboratory, we immediately divided all 16 focal nests from the supercolony site into two boxes to control for the possibility that physical separation in the laboratory causes aggression in the assays. We reared the laboratory nests in room temperature for three to eight days, kept them moist, and fed them daily with a Bhatkar-Whitcomb diet (Bhatkar \& Whitcomb, 1970).

We tested the reaction of workers from each of the 16 supercolony site nests against control, neighbor, distant, outside, and allospecific individuals (Figure 3). We replicated each of the five treatments five times per nest with new arenas and new individuals, except for the allospecific tests. The latter we performed in the same arenas with the same individuals as the same-nest control treatments, as there never was any aggression in the control treatments. Our preliminary experiments showed that F. pressilabris workers act passively in standard one-on-one aggression assays on neutral arenas, usually showing no interest toward each other. Therefore, we used experimental arenas (6.5-cm-diameter fluon-coated, newly purchased plastic cups) with 15 workers on their own nest material, simulating natural conditions with nestmates and familiar odors present. In an assay like this, the observed behavior is expected to correlate with the natural nest defense behavior, revealing whether the workers would allow visitors to enter their nest or not, as even submissive ant species defend their nests against intruders (Savolainen \& Vepsäläinen, 1988; Vepsäläinen \& Pisarski, 1982). If an assay this sensitive does not show aggression, this can be interpreted as very strong potential for cooperation: When ants are willing to share their nest, they probably cooperate in other ways, too. After letting the 15 focal ants calm down (when they had stopped running around and did not show signs of alert, such as opening their mandibles), we introduced one worker from another laboratory nest box. We recorded the actions of the ants for one minute from the introduction, using a Canon EOS 550D DSLR camera with a Canon EF $100 \mathrm{~mm}$ f/2,8 macro lens. The distance between the ants and the lens was $48.5 \mathrm{~cm}$. Ants did not react toward the camera. We performed the behavioral assays on July 3-7, 2016.

One of the authors (MI) watched and transcribed the videos in a randomized order at half speed and blindly regarding which nests and which treatments were represented in each video. The durations of antennation, trophallaxis, and biting events against 


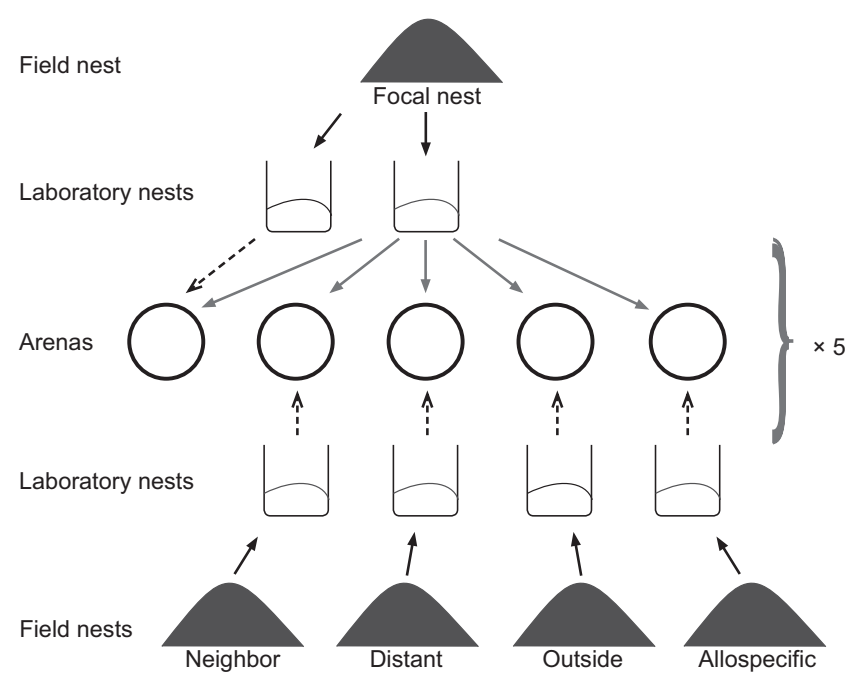

FIGURE 3 The design of the behavioral experiment. In each assay, we tested the reactions of 15 ants from a focal nest toward one ant from another laboratory nest box. We collected ants and nest material into laboratory nest boxes (black arrows) and put 15 workers from a focal nest into each of five experimental arenas (gray arrows). Then, we introduced one worker from another laboratory nest into the arenas (dashed arrows). For each focal nest, we replicated this procedure five times with new ants and arenas. Control = introduced ant from the same nest, Neighbor = introduced ant from the same part of the supercolony field, Distant = introduced ant from a different part from the supercolony field, Outside $=$ introduced ant from another field, Allospecific $=$ introduced ant of a different species, F. exsecta

the one introduced worker were recorded using the software JWatcher 1.0. We could not reliably score behavior frequencies or minor signs of aggression such as mandible opening due to the large number of individuals on the arena and the small size of the ants. The scoring was hierarchical in the sense that when even one of the fifteen focal individuals was aggressive, we did not score nonaggressive behavior at the same time, because aggression-related pheromones could affect the behavior of other individuals. In our analyses, we combined trophallaxis and antennation as nonaggressive inspecting behavior, because the two were sometimes hard to separate from each other and both have been shown to increase when individuals recognize the opponent as a non-nestmate in polydomous Formica paralugubris (Chapuisat et al., 2005; Holzer et al., 2006). Seven out of the 400 videos could not be analyzed due to damaged files.

\section{3 | Statistical analysis of behavioral data}

We analyzed the presence and absence of aggression explained by the different treatment classes with a binomial generalized linear mixed model (GLMM). In all of our models, we included both the nest of the focal workers and the nest of the introduced worker as random effects to account for the nonindependence of samples coming from the same nest. We excluded the "control" treatment as no aggression occurred in the within-nest controls. We used a beta GLMM to analyze the duration of aggression among the treatment classes where it occurred. For the videos where no aggression occurred, we also used a beta GLMM to analyze the duration of nonaggressive inspecting behavior (antennation and trophallaxis combined). For this analysis, we excluded the treatment level "allospecific" due to low sample size $(n=3)$, and substituted five samples with a value of 0 (= no inspecting behavior) with a value of 1 (= a millisecond of inspecting behavior) to allow the use of the beta distribution, which cannot contain zeros. For the beta GLMM's, we measured the duration of aggression or inspecting behavior as the proportion of the total time that the introduced ant was in sight.

We further tested whether the geographical distance between two separate nests explains the presence or duration of aggression, or the duration of nonaggressive inspecting behaviors. We analyzed a subset of our behavioral data within the supercolony site (treatment levels "neighbor" and "distant"), using a binomial GLMM for the presence of aggression and beta GLMM for the duration of aggression and inspecting behavior. Geographical and genetic distances are collinear in our data (see below), and the effect of these two variables cannot be fully separated in our results. Therefore, we used only geographical distance as an explanatory variable in our analysis. As we did the genetic analysis only for a single individual per nest, using genetic distance would be more problematic in connection to the nest-level behavioral data. Additionally, conspecific aggression in ants correlates mostly with chemical distance (Martin, Vitikainen, Drijfhout, \& Jackson, 2012) which may have both genetic and environmental components (Ginzel \& Blomquist, 2016; Vander Meer \& Morel, 1998). Thus, as geographical distance contains information of both genetic and environmental factors, we deemed it more biologically relevant than genetic distance. We analyzed the behavioral data in $\mathrm{R}$ ( $\mathrm{R}$ Core Team, 2013) with the package glmmTMB (Bolker et al., 2009).

\subsection{DNA microsatellite genotyping and population genetics}

To estimate gene flow among and within the four sites, we genotyped a single worker from 285 different nests, including 233 nests from the supercolony site (Figure 2 ) and all nests from the three smaller study sites. We extracted the DNA using NucleoSpin Tissue extraction kits (Macherey-Nagel) and genotyped the samples with 14 DNA microsatellite markers originally developed for other Formica species (Chapuisat, 1996; Gyllenstrand, Gertsch, \& Pamilo, 2002; Hasegawa \& Imai, 2004; Trontti, Tay, \& Sundström, 2003) using the protocol designed by Hakala et al. (2018). We scored the DNA microsatellite alleles with the software GeneMapper 5 (Applied Biosystems).

We analyzed linkage disequilibrium and Hardy-Weinberg equilibrium using GenePop on the Web (Raymond \& Rousset, 1995; Rousset, 2008) and calculated allelic richness values using the PopGenReport 3.0.0 package (Adamack \& Gruber, 2014) in R. We calculated allele frequencies, linear genetic distances between nests, and heterozygosity values using GenAIEx 6.502 (Peakall 
\& Smouse, 2012). We calculated $\mathrm{F}_{\mathrm{ST}}$ values among all sampled sites, and among the four parts within the supercolony field using AMOVA's in GenAIEx 6.502 (Peakall \& Smouse, 2012). To test for genetic viscosity, we performed Mantel tests using the package ecodist 2.0.1 (Goslee \& Urban, 2007) in R.

We analyzed the genetic structure of the population with a Bayesian approach using the software STRUCTURE 2.3.4 (Pritchard, Stephens, \& Donnelly, 2000), which clusters individual genotypes by the probability of similarity. To determine the most likely number of clusters $(\mathrm{K})$, the analysis was run with $\mathrm{K}$ ranging from 1 to 7, using the admixture model and correlated allele frequencies. For each $\mathrm{K}$ value, we ran the analysis ten times with a burn-in of 100,000 steps for a run length of 300,000 steps. We estimated the most likely number of clusters by applying the delta $\mathrm{K}$ method with plotting the mean and standard deviation of the mean likelihood $L(K)$ for each run in STRUCTURE HARVESTER (Earl \& vonHoldt, 2012; Evanno, Regnaut, \& Goudet, 2005). As the mathematical model used by STRUCTURE is not ideal with unbalanced sampling and groups with low sample sizes or patterns of isolation by distance (Kalinowski, 2011; Puechmaille, 2016), we repeated the genetic mixture analysis with a similar software, BAPS 6.0 (Corander \& Marttinen, 2006; Corander, Siren, \& Arjas, 2008; Corander, Waldmann, \& Sillanpää, 2003). BAPS was allowed to find the most probable number of clusters with repeated runs (10 times K1-K7). As BAPS was unable to find any stable clustering without a spatial prior, we repeated the analysis as a spatial analysis with geographical coordinates. Subsequently, we performed an admixture analysis with the results of the spatial analysis.

\section{3 | RESULTS}

\section{1 | Mapping of the study area}

The supercolony site had more than 1,300 nests, and the nest densities ranged from 254 to 401 nests/ha in the different parts of the site. The three smaller sites had 7, 16, and 29 nests, and the nest densities were 426, 25, and 25 nests/ha, respectively (Figure 2, Table A1). We could not directly observe worker movement between nests, because F. pressilabris workers walk mostly on the ground surface under the grass cover or on grass stems, forming no visible paths between the nests. All parts of the supercolony site had many dense aggregations with nests situated very closely together. Often these aggregations had one or two large main nests and a few smaller ones. The distances between nest aggregations were often short, and the field is overall almost uniformly occupied by the species.

\section{2 | Behavioral assays}

There was no aggression in the same-nest controls, while the allospecific treatment with F. exsecta had aggression in 72 out of 75

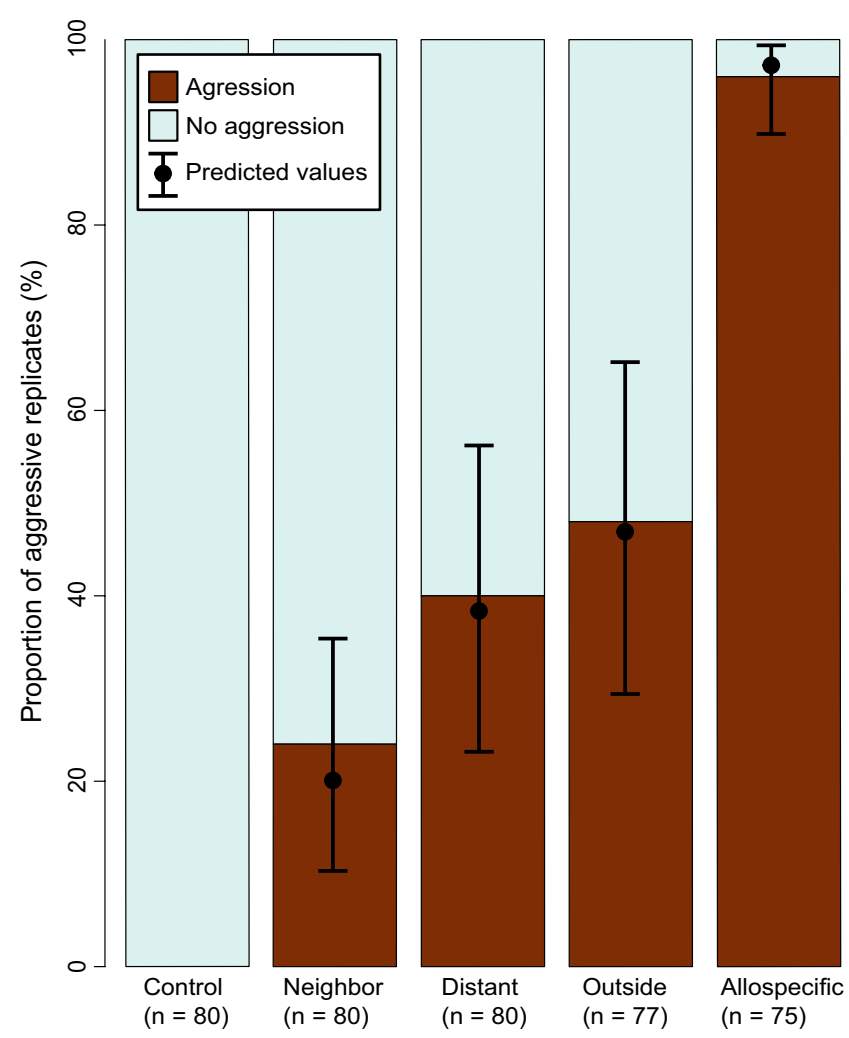

FIGURE 4 Presence and absence of aggression by treatment with model predictions for the four treatment classes that we included in the analysis (binomial GLMM). The control treatment, which had no aggression, was excluded from the model. Among those treatment classes that were included, all other pairwise differences were significant, except the difference between distant and outside. Control = introduced ant from the same nest, Neighbor $=$ introduced ant from the same part of the supercolony field, Distant $=$ introduced ant from a different part from the supercolony field, Outside = introduced ant from another field, Allospecific $=$ introduced ant of a different species, F. exsecta

assays (Figure 4). In the neighbor, distant, and outside treatments, there was clearly more aggression than in the completely nonaggressive control treatments. Aggression occurred significantly more often in the allospecific than in any other treatment (compared to Neighbor: $Z=6.71, S E=0.73, p<.001$; Distant: $Z=5.64, S E=0.71$, $p<.001$; Outside: $Z=5.08, S E=0.72, p<.001$ ). The workers were also more often aggressive toward conspecific ants from distant nests than those from neighbor nests $(Z=2.23, S E=0.40, p=.026)$. However, there was no significant difference between the aggression faced by ants from distant and outside nests (full test statistics in Table A2). The behavioral patterns were not consistent among the five replicates; instead, there were aggressive and nonaggressive interactions among and within all parts of the supercolony site. There were plenty of nonaggressive replicates also between distant nest pairs (Figure 5).

In the assays where aggression occurred, its duration did not significantly differ among the treatments, except in one of the pairwise comparisons, where the effect size remained small (Figure 6). However, the allospecific treatment always had long aggression 
FIGURE 5 The number of replicates (out of five) with aggression for each nest pair within the supercolony site. The nests used in the aggression assays are shown as red triangles, and other nests as gray circles. The colored arrows show the number of aggressive replicates (see legend), and arrowheads show the direction of aggression, pointing toward the nest of the introduced ant

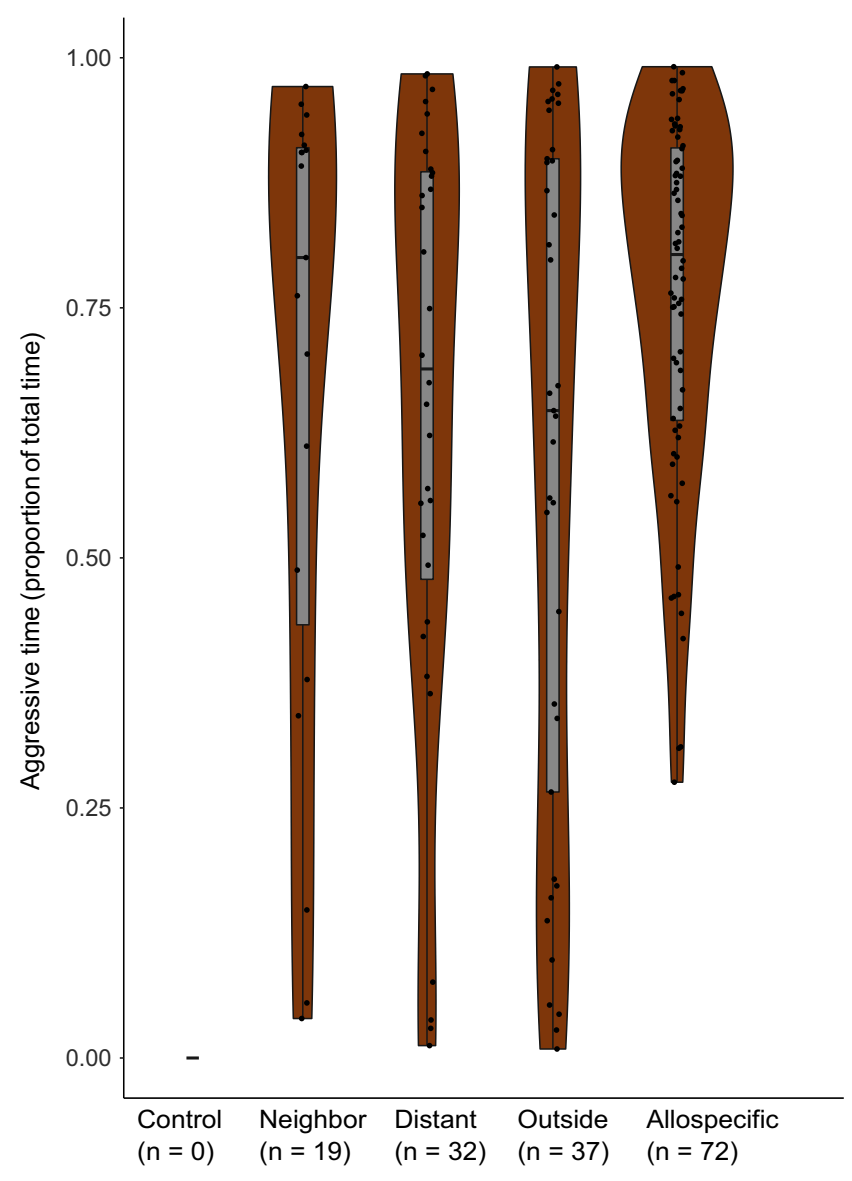

FIGURE 6 Duration of aggression (when present) by treatment as proportion of the total observation time. All data points, density plot, and median and quartile plot (box plot) shown. Only the difference between "outside" and "allospecific" is statistically significant (beta GLMM: $X=2.43, S E=0.23$, $p=.015)$. Control $=$ introduced ant from the same nest, Neighbor = introduced ant from the same part of the supercolony field, Distant = introduced ant from a different part from the supercolony field, Outside $=$ introduced ant from another field, Allospecific $=$ introduced ant of a different species, F. exsecta

durations ( $>25 \%$ of the assay time), whereas all within-species treatments also included shorter durations ( $<25 \%$ of the assay time). In the assays without aggression, significantly less inspecting behavior was targeted toward the control than any of the other treatments (compared to Neighbor: $Z=5.45, S E=0.19, p<.001$; Distant: $Z=5.07$,
$S E=0.20, p<.001$; Outside: $Z=3.74, S E=0.34, p<.001$ ), while none of the other treatments differed from each other (Figure 7, Table A2).

Within the supercolony site, the occurrence of aggression between two nests increased with geographical distance (Figure 8a, binomial GLMM, $z=2.85, S E=1.20, p=.004$ ), but its duration did not change with distance (Figure 8b, beta GLMM z $=-0.334, S E=0.94$, $p=.74)$. The duration of inspecting behavior between nests within the supercolony field did not change with increasing distance (beta GLMM, $z=0.36, S E=0.66, p=.72$ ).

\section{3 | Population genetics}

Of the original 14 DNA microsatellite markers, we used 10 for further analysis, as four had too much missing data or significant heterozygote deficiency at all study sites (details in Tables S1-S6). The pairwise $F_{\mathrm{ST}}$ values show that the four parts of the supercolony site differed genetically from each other and that this differentiation was on a level similar to the differentiation among the other study sites (Table 1). Mantel tests showed minor but significant genetic viscosity when analyzing all samples in the study area $(R=0.06,95 \%$ $\mathrm{Cl}=0.04,0.08 ; p=.038$ ), and also when analyzing only the samples from the supercolony site $(\mathrm{R}=0.1,95 \% \mathrm{Cl}=0.09,0.12 ; p \leq .001)$.

In the Bayesian clustering for the study area (Figure $9 \mathrm{a}, \mathrm{b}$ ), the optimal number of genetic clusters was two according to STRUCTURE HARVESTER ( $\Delta K=99.9$, details in Table S6 (Evanno et al., 2005)) and three according to BAPS (posterior probability $=0.981$ ). However, the obtained clusters did not correspond to the different locations, as both analyses showed some sites to contain a mixture of individuals belonging to different clusters. The results from STRUCTURE revealed strong genetic admixture among individuals, whereas BAPS found admixture only in a few individuals. The four sampled sites seem to belong to a single population with gene flow among the sites.

\section{4 | DISCUSSION}

We found minor genetic viscosity on a small spatial scale, both within the supercolonial site and in its close surroundings. This indicates limited dispersal within the study area, as expected if new 


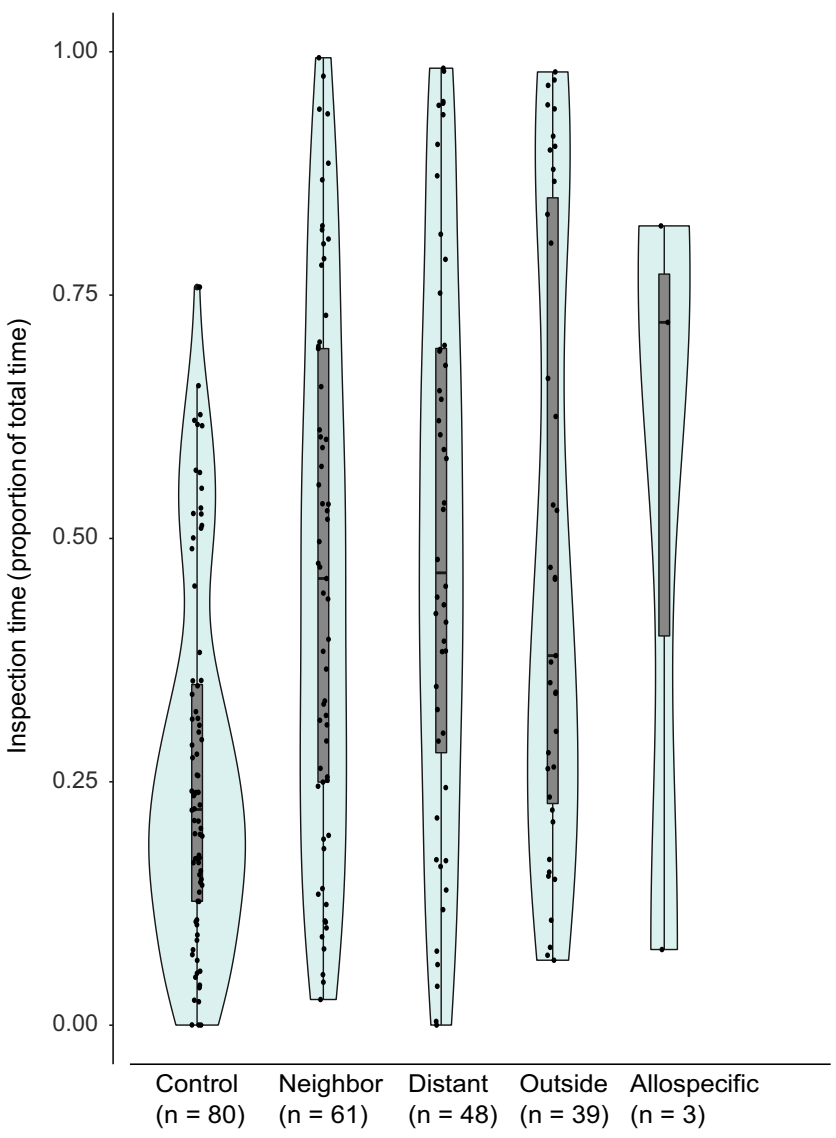

FIGURE 7 Duration of inspection behavior (antennation and trophallaxis) by treatment in the nonaggressive samples as proportion of the total observation time. All data points, density plot, and median and quartile plot (box plot) shown. Only the treatment Control is significantly different from other classes (beta GLMM, allospecific treatment not included in the model due to $n=3$ ). Control = introduced ant from the same nest, Neighbor $=$ introduced ant from the same part of the supercolony field, Distant $=$ introduced ant from a different part from the supercolony field, Outside = introduced ant from another field, Allospecific $=$ introduced ant of a different species, F. exsecta

nests are formed mostly by budding from parent nests. However, the fact that the different sites are not genetically more differentiated than different parts of the supercolony site indicates that some dispersal by flight also occurs. Behavioral experiments within the densely populated supercolony site show a similar behavioral pattern: The overall aggression level is low, workers mostly tolerate visitors from other nests in conditions simulating their own nest environment, and geographically close nests are better tolerated than nests further away. This suggests potential for cooperation among adjacent nests, and this potential slightly decreases the further nests are apart. However, because we observed some aggression within the supercolony site, it does not seem to consist of a single, distinct supercolony. There might be a mosaic of multiple supercolonies at the site, but as our data do not reveal any clear-cut behavioral borders, it is possible that the different colonies are somewhat connected over the whole spatial scale.

\section{1 | Gene flow and dispersal}

Our population genetic data indicate limited dispersal within the supercolony site. Even though within-nest relatedness is low, probably due to polygyny and mixing of individuals among adjacent nests (Schultner et al., 2014), individuals do not seem to mix effectively across the entire supercolony site, not even winged sexual individuals. Such genetic viscosity at a site less than $1 \mathrm{~km}$ across shows that these ants disperse mostly over very short distances. Local mating between nestmates or individuals from neighboring nests must be common, as the population would otherwise not remain even weakly genetically viscous. F. exsecta, which is closely related and ecologically similar to F. pressilabris, has similar levels of genetic viscosity in its supercolonies (Seppä et al., 2012). In Formica paralugubris, a supercolony was more viscous than the surrounding nonsupercolonial population, which, just as our results, suggests that supercoloniality is linked to locally reduced dispersal (Chapuisat et al., 1997). Importantly, data on gene flow, such as in the above-mentioned cases, do not provide any information about failed dispersal attempts. Workers in existing nests have a key role in determining which sexual individuals can establish themselves as reproducers at the supercolony site. Aggressive behavior toward individuals from distant nests could make their establishment as reproducers hard, even if they tried.

On a slightly larger spatial scale, the supercolony site is not genetically distinct from surrounding smaller polydomous colonies. Instead, pairwise $\mathrm{F}_{\mathrm{ST}}$ values among the small sites and among the different parts of the supercolony site are in the same range. Our data suggest that longer-range dispersal among different sites is frequent enough to keep population structuring low (Table 1), although dispersal seems to be limited within the supercolony site. Ongoing long-range dispersal ensures that the supercolony is not a closed population, and extends the scale of competition beyond single sites, which may give some selective advantage to the individuals from the supercolony on larger spatial scales (Kennedy, Uller, \& Helanterä, 2014; Pedersen et al., 2006). This contrasts with previous findings in F. exsecta, where polydomous colonies were genetically more different from surrounding monodomous and monogynous colonies than these were from each other (Gyllenstrand, Seppä, \& Pamilo, 2005; Seppä et al., 2004), suggesting that polydomous colonies could form closed populations without much dispersal outwards.

Unfortunately, with our data we cannot assess whether dispersal is sex-biased. Male-biased dispersal is common in polygynous ants (Hakala, Seppä, \& Helanterä, 2019) and in Formica overall (Sundström et al., 2005). In socially parasitic Formica species, such as our study species, queen dispersal is further complicated by the fact that queens cannot found their nests alone, but have to parasitize a nest of their host species or possibly another nest of their own species (Buschinger, 2009; Czechowski, 1975). Reduced queen dispersal, or queen dispersal predominantly among existing colonies instead of founding new ones, would impair the colonization potential even if dispersal abilities were good, as suggested by gene flow among sites. Indeed, there are plenty of empty potential habitat 
FIGURE 8 (a) Presence of aggression between different nests at the supercolony site as a function of internest distance, data (dots), and prediction (line with 95\% confidence intervals) according to a binomial GLMM). $N=160$. Darker dots indicate several data points on top of each other. (b) Duration of aggression (when present) between different nests as a function of distance on the supercolony field, data (dots), and nonsignificant prediction (line with confidence intervals according to beta GLMM). $N=51$ (a)

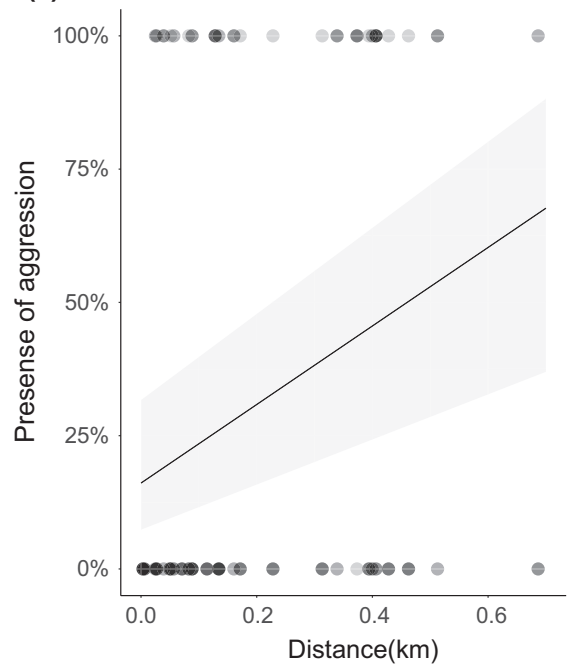

(b)

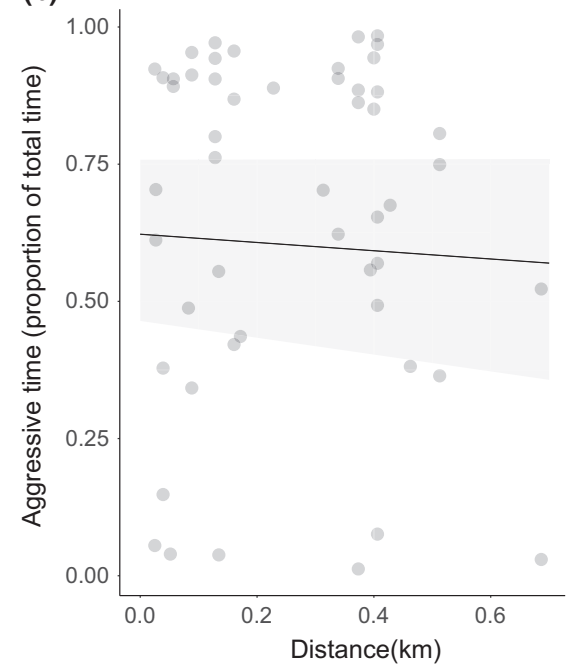

TAB LE 1 Pairwise $F_{\mathrm{ST}}$ values between subpopulations from an AMOVA with 999 permutations

\begin{tabular}{|c|c|c|c|c|c|c|}
\hline & \multicolumn{6}{|c|}{ Särkkilen I } \\
\hline & & \multicolumn{5}{|c|}{ Särkkilen II } \\
\hline Särkkilen II & \multicolumn{2}{|l|}{0.015} & \multicolumn{4}{|c|}{ Särkkilen III } \\
\hline Särkkilen IV & 0.065 & 0.074 & 0.031 & \multicolumn{3}{|c|}{ Storsand } \\
\hline Storsand & 0.041 & 0.042 & 0.074 & 0.102 & & Lillgård \\
\hline Storgård & 0.034 & 0.037 & 0.054 & 0.080 & 0.039 & 0.059 \\
\hline
\end{tabular}

Note: The supercolony site (Särkkilen) is divided into four parts according to Figure 2b. All values are significantly different from zero ( $p \leq .001)$.

FIGURE 9 (a) Bayesian clustering of all genotyped individuals from the four study sites (I-IV = the four different parts of the supercolony site) with the software STRUCTURE. Samples organized from west to east. Optimal $K=2$ with strong admixture. (b) Bayesian clustering of the same data with the software BAPS. Optimal $K=3$ with less admixture

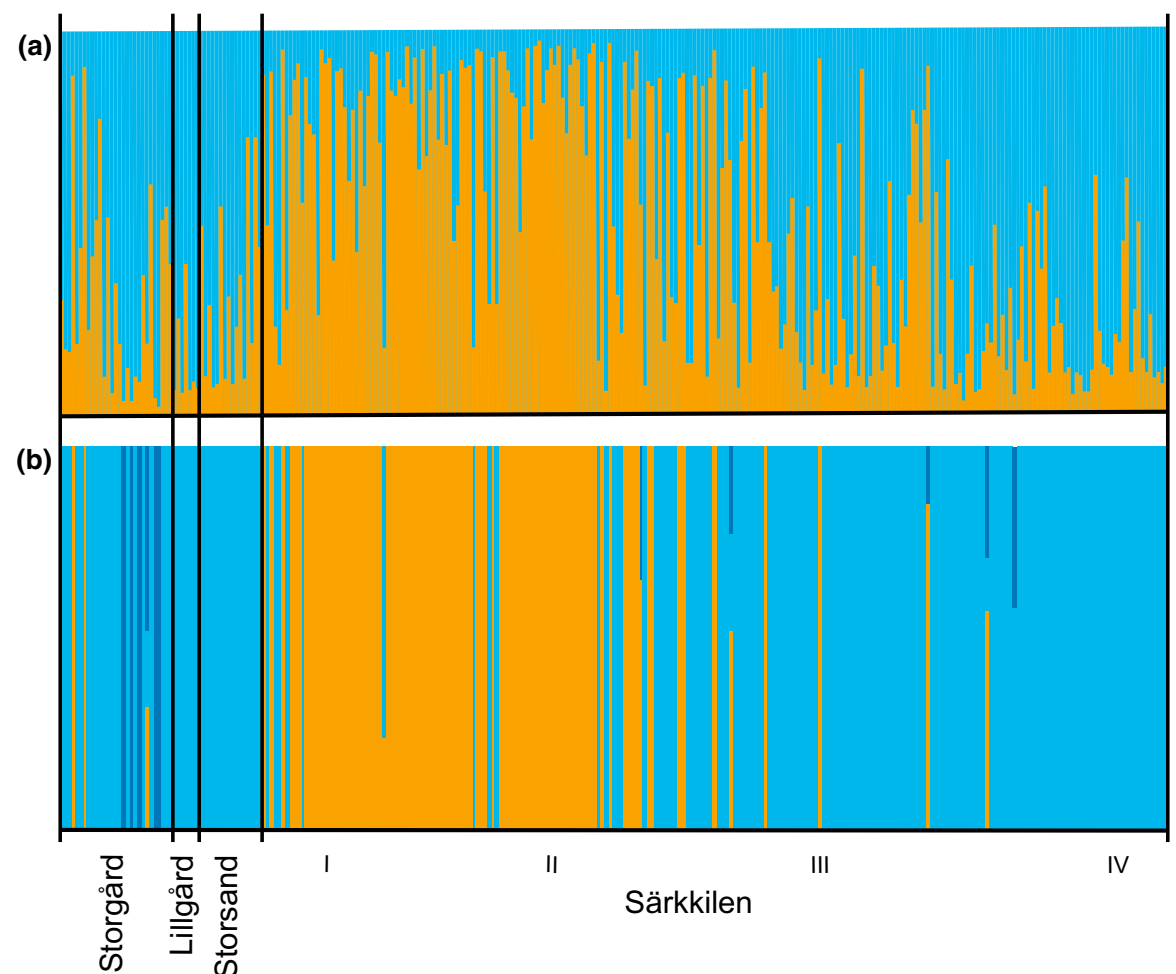


patches around the supercolony in our study area, which speaks for limited colonization. Overall, the dispersal strategy of F. pressilabris seems twofold: Risky long-range dispersal combined with high levels of queen philopatry and potential to spread locally through shortrange dispersal by foot. Such a dual strategy seems to be the rule in polygynous and polydomous Formica (Sundström et al., 2005) and exists in other ant taxa too, for example, in Crematogaster pygmaea (Hamidi et al., 2017).

\subsection{Aggression patterns and potential for cooperation}

Our main study site is, to our knowledge, the largest described nest aggregation of Formica pressilabris and among the largest of any species in the Coptoformica subgenus (Czechowski, 1971, 1975; Markó et al., 2012). The nest densities (Table A1) are well in line with previously reported values for large polydomous systems of Formica (Markó et al., 2012). While we are not aware of any reported nest densities for monodomous F. pressilabris, Pamilo and Rosengren (1984) reported clearly lower values (1.16-3.11 nests/ ha) for three monodomous F. exsecta populations. The nest densities and observed high tolerance for introduced workers make us confident that the supercolony field is polydomous to a large degree. However, our behavioral assays still suggest that this nest aggregation is not a uniformly cooperative supercolony. Aggression generally increases with distance, but there are plenty of exceptions and no distinguishable colony borders (Figure 5). More detailed data on genetic and chemical similarity of the nests would be required for dissecting the ultimate reasons and mechanisms for this pattern. This behavioral pattern resembles a phenomenon already suggested possible by Moffett (2010, 2012): a social equivalent of a ring species, where all individuals that meet each other in natural settings interact peacefully, and all of the nests can thus be considered to belong to one colony, but individuals may act aggressively when experimentally brought together from distant parts of the range.

In contrast to our data, dense and spatially distinct polydomous nest aggregations often show a complete lack of aggression, for example, in both native and introduced argentine ants (BjörkmanChiswell, Wilgenburg, Thomas, Swearer, \& Elgar, 2008; Giraud et al., 2002; Vogel et al., 2009), introduced Myrmica rubra (Chen, O'sullivan, \& Adams, 2018), and native Formica (Chapuisat et al., 2005; Holzer et al., 2006; Kidokoro-Kobayashi et al., 2012; Pohl et al., 2018). However, some previous studies have also shown aggression within large polydomous Formica exsecta colonies (Katzerke, Neumann, Pirk, Bliss, \& Moritz, 2006; Pisarski, 1982). Observations of seasonal and resource-dependent differences in aggression levels (Katzerke et al., 2006; Mabelis, 1979, 1984; Sorvari \& Hakkarainen, 2004), and seasonal variation in supercolony genetic structure (Elias et al., 2005; Schultner, Saramäki, \& Helanterä, 2016), suggest that further temporal analysis of aggression patterns in supercolonial Formica is needed.
In addition to the current study, positive correlations between aggression and spatial distance have been reported, for example, within polydomous sites of $F$. exsecta (Katzerke et al., 2006) and Myrmica rubra (Fürst, Durey, \& Nash, 2012; Garnas, Drummond, \& Groden, 2007), although later Chen et al. (2018) did not find such a correlation in M. rubra. Importantly, Chen et al. (2018) had, through a previous set of aggression assays, assigned colony borders prior to testing for this relationship and suggest that the correlations between geographical distance and aggression found by Garnas et al. (2007) and Fürst et al. (2012) may be attributed to mixing nest pairs belonging to the same and different colonies in one analysis. Our supercolonial site may indeed consist of multiple supercolonies instead of one, but the lack of clear patterns and the overall low levels of aggression revealed in our study (Figure 5) lend little support to the existence of clear and persistent borders at our study site. Finally, aggression has been shown to increase with internest distance also in monodomous species (Beye, Neumann, Chapuisat, Pamilo, \& Moritz, 1998) and among distinct colonies or sites (Holzer et al., 2006; Pirk, Neumann, Moritz, \& Pamilo, 2001; Rosengren, Cherix, \& Pamilo, 1986; Zinck, Hora, Châline, \& Jaisson, 2008), making these kinds of behavioral patterns hard to interpret.

The different behavioral assay methods used in many of the studies discussed above make direct comparisons of the results difficult (Roulston et al., 2003). Our method, where 15 individuals on their own nest material met one introduced ant, is very sensitive to aggression as it simulates an alien ant suddenly appearing in a nest, and there are many ants that can react. Based on our pilot experiments, we consider it likely that F. pressilabris would have shown even less, if any, aggression in some more commonly used assay types, such as one-on-one tests on neutral arenas. Even in the absence of aggression, our results show that workers spend more time inspecting any non-nestmates than nestmates. Thus, workers may distinguish between nestmates and more distant individuals, as is also suggested by increased antennation and trophallaxis in F. paralugubris (Chapuisat et al., 2005; Holzer et al., 2006), and increased antennation in argentine ants (Björkman-Chiswell et al., 2008).

While a lack of aggression between nests is commonly interpreted as a sign of shared colony identity, it does not necessarily mean that two nests share resources (Buczkowski, 2012; Giraud et al., 2002; Heller, Ingram, \& Gordon, 2008). In large nest aggregations, it is relevant to ask what the true spatial scale of cooperation and competition is (Pedersen, 2012). At our supercolony site, aggression did not always occur even when testing over the nest-free gap in the middle of the field, showing that workers are willing to let individuals from relatively far away enter their nests (Figure 5). Czechowski (1975) found that workers can move at least 20-30 m between nests in supercolonies of F. pressilabris, but such movements were considerably rarer than movements among nearer nests. In F. exsecta, workers from polydomous colonies forage on trees less than ten meters from a central nest (Sorvari, 2009). Thus, given the width of the gap ( $70 \mathrm{~m})$ at our main study site, worker movements over it should be rare, and we consider true 
cooperation, such as transfer of brood or resources, over this gap unlikely. If resources are shared over relatively limited distances also at our study site, the two field halves should be considered functionally separate colonies, even though they are not clearly distinct based on either genetic or behavioral data. We agree with Heller et al. (2008) and Lester and Gruber (2012) in their arguments that functional cooperation and resource sharing is a crucial component when considering the evolution and maintenance of supercolonies. To be able to assess true relatedness among cooperating individuals, we need to understand which parts of assumed supercolonies truly cooperate, and whether there are seasonal or resource-dependent patterns. Without this knowledge, it is not possible to assess whether competition happens more within or among assumed supercolonies.

The genetic viscosity corresponds to the behavioral pattern where workers from nearby nests were allowed to enter the nest material more than distant workers. This suggests that limited dispersal does result in cooperation among relatives in Formica supercolonies. As our genetic data suggest that competition over reproduction is not exclusively local, local cooperation even under low but positive relatedness may help maximizing reproductive success on a larger spatial scale. The F. pressilabris nest aggregation described in this study is extremely dense and seemingly supercolonial. However, it defies usual definitions of ant colonies as single cooperative units with clear borders. Based on our behavioral data, discrimination in $F$. pressilabris is fluid, which begs for further studies on the functional connectedness of the nests, and the cooperative behavior in more natural settings in the field. Truly understanding the nature of supercoloniality requires more functional studies focusing on resource sharing and competitive dynamics-in all ant taxa exhibiting this fascinating lifestyle.

\section{ACKNOWLEDGMENTS}

Matti Leponiemi and Eeva Vakkari kindly helped with field work, and Heini Ali-Kovero and Leena Laaksonen with genetic analyses. Our work was funded by the Academy of Finland (\#140990, \#135970, \#251337, \#284666). SH was funded by Finnish Cultural Foundation and Alfred Kordelin Foundation; MI was funded by Betty Väänänen foundation, Societas Pro Fauna et Flora Fennica, Societas Biologica Fennica Vanamo, Suomen Hyönteistieteellinen Seura ry, Helsingin hyönteistieteellinen yhdistys, the Swedish Research Council, and the Bolin Centre for Climate Research; and HH was funded by Kone foundation.

\section{CONFLICT OF INTEREST}

The authors declare no conflict of interest.

\section{AUTHOR CONTRIBUTIONS}

All authors designed and conceived the study. Ml collected the data. SMH and MI analyzed the data, prepared figures and tables, and drafted the manuscript. All authors reviewed drafts and approved the final manuscript.

\section{DATA AVAILABILITY STATEMENT}

The data used in this study are archived in the Dryad Digital Repository: https://doi.org/10.5061/dryad.ffbg79cr2.

\section{ORCID}

Sanja M. Hakala iD https://orcid.org/0000-0002-3762-623X

Mats Ittonen iD https://orcid.org/0000-0002-4628-0584

\section{REFERENCES}

Adamack, A. T., \& Gruber, B. (2014). PopGenReport: Simplifying basic population genetic analyses in R. Methods in Ecology and Evolution, 5(4), 384-387. https://doi.org/10.1111/2041-210X.12158

Ascunce, M. S., Yang, C.-C., Oakey, J., Calcaterra, L., Wu, W.-J., Shih, C.-J. ... Shoemaker, D. (2011). Global invasion history of the fire ant Solenopsis invicta. Science, 331(6020), 1066-1068.

Beye, M., Neumann, P., Chapuisat, M., Pamilo, P., \& Moritz, R. F. A. (1998). Nestmate recognition and the genetic relatedness of nests in the ant Formica pratensis. Behavioral Ecology and Sociobiology, 43(1), 67-72. https://doi.org/10.1007/s002650050467

Bhatkar, A., \& Whitcomb, W. H. (1970). Artificial diet for rearing various species of ants. The Florida Entomologist, 53(4), 229-232.

Björkman-Chiswell, B. T., van Wilgenburg, E., Thomas, M. L., Swearer, S. E., \& Elgar, M. A. (2008). Absence of aggression but not nestmate recognition in an Australian population of the Argentine ant Linepithema humile. Insectes Sociaux, 55(2), 207-212. https://doi. org/10.1007/s00040-008-0990-9

Bolker, B. M., Brooks, M. E., Clark, C. J., Geange, S. W., Poulsen, J. R., Stevens, M. H. H., \& White, J.-S.-S. (2009). Generalized linear mixed models: A practical guide for ecology and evolution. Trends in Ecology \& Evolution, 24(3), 127-135.

Bönsel, A. (2007). Nest turnover in a colony of Formica pressilabris Nylander, 1846 as related to habitat quality (Hymenoptera: Formicidae). Opuscula Zoologica Fluminensia, 222, 1-12.

Boomsma, J. J. (2009). Lifetime monogamy and the evolution of eusociality. Philosophical Transactions of the Royal Society B: Biological Sciences, 364(1533), 3191-3207. https://doi.org/10.1098/ rstb.2009.0101

Boomsma, J. J., Huszár, D. B., \& Pedersen, J. S. (2014). The evolution of multiqueen breeding in eusocial lineages with permanent physically differentiated castes. Animal Behavior, 92, 241-252. https://doi. org/10.1016/j.anbehav.2014.03.005

Bourke, A. F. G. (2011). Principles of social evolution, Oxford series of ecology and evolution. Oxford: Oxford University Press.

Brandt, M., van Wilgenburg, E., \& Tsutsui, N. D. (2009). Global-scale analyses of chemical ecology and population genetics in the Argentine ant. Molecular Ecology, 18(5), 997-1005.

Buczkowski, G. (2012). Colony spatial structure in polydomous ants: Complimentary approaches reveal different patterns. Insectes Sociaux, 59(2), 241-250. https://doi.org/10.1007/s0004 0-011-0211-9

Buschinger, A. (2009). Social parasitism among ants: A review (Hymenoptera: Formicidae). Myrmecological News, 12(3), 219-235.

Chapuisat, M. (1996). Characterization of microsatellite loci in Formica lugubris $\mathrm{B}$ and their variability in other ant species. Molecular Ecology, 5(4), 599-601. https://doi.org/10.1111/j.1365-294X.1996.tb003 54.x

Chapuisat, M., Bernasconi, C., Hoehn, S., \& Reuter, M. (2005). Nestmate recognition in the unicolonial ant Formica paralugubris. Behavioral Ecology, 16(1), 15-19. https://doi.org/10.1093/beheco/arh128

Chapuisat, M., Goudet, J., \& Keller, L. (1997). Microsatellites reveal high population viscosity and limited dispersal in the ant Formica paralugubris. Evolution, 51(2), 475-482. 
Chen, W., O'sullivan, Á., \& Adams, E. S. (2018). Intraspecific aggression and the colony structure of the invasive ant Myrmica rubra. Ecological Entomology, 43(2), 263-272. https://doi.org/10.1111/ een.12500

Collingwood, C. (1979). The Formicidae (Hymenoptera) of Fennoscandia and Denmark. Fauna Entomolgica Scandinavica, 8, 64.

Corander, J., \& Marttinen, P. (2006). Bayesian identification of admixture events using multilocus molecular markers. Molecular Ecology, 15(10), 2833-2843. https://doi.org/10.1111/j.1365-294X. 2006.02994.x

Corander, J., Siren, J., \& Arjas, E. (2008). Bayesian spatial modeling of genetic population structure. Computational Statistics, 23(1), 111-129. https://doi.org/10.1007/s00180-007-0072-x

Corander, J., Waldmann, P., \& Sillanpää, M. J. (2003). Bayesian analysis of genetic differentiation between populations. Genetics, 163(1), 367-374.

Crespi, B. J., \& Yanega, D. (1995). The definition of eusociality. Behavioral Ecology, 6(1), 109-115.

Cronin, A. L., Molet, M., Doums, C., Monnin, T., \& Peeters, C. (2013). Recurrent evolution of dependent colony foundation across eusocial insects. Annual Review of Entomology, 58(1), 37-55. https://doi. org/10.1146/annurev-ento-120811-153643

Czechowski, W. (1971). Competition between Formica exsecta Nyl. and Formica pressilabris Nyl. (Hymenoptera, Formicidae). Annales Zoologici, 17, 273-286.

Czechowski, W. (1975). Bionomics of Formica (Coptoformica) pressilabris Nyl. (Hymenoptera, Formicidae). Annales Zoologici, 33(8), 103-125.

Debout, G., Schatz, B., Elias, M., \& McKey, D. (2007). Polydomy in ants: What we know, what we think we know, and what remains to be done. Biological Journal of the Linnean Society, 9(2), 319-348.

Earl, D. A., \& vonHoldt, B. M. (2012). STRUCTURE HARVESTER: A website and program for visualizing STRUCTURE output and implementing the Evanno method. Conservation Genetics Resources, 4(2), 359-361. https://doi.org/10.1007/s12686-011-9548-7

Elias, M., Rosengren, R., \& Sundström, L. (2005). Seasonal polydomy and unicoloniality in a polygynous population of the red wood ant Formica truncorum. Behavioral Ecology and Sociobiology, 57(4), 339349. https://doi.org/10.1007/S00265-004-0864-8

Ellis, S., \& Robinson, E. J. H. (2014). Polydomy in red wood ants. Insectes Sociaux, 61(2), 111-122. https://doi.org/10.1007/s0004 0-013-0337-z

Evanno, G., Regnaut, S., \& Goudet, J. (2005). Detecting the number of clusters of individuals using the software STRUCTURE: A simulation study. Molecular Ecology, 14(8), 2611-2620. https://doi. org/10.1111/j.1365-294X.2005.02553.x

Fürst, M. A., Durey, M., \& Nash, D. R. (2012). Testing the adjustable threshold model for intruder recognition on Myrmica ants in the context of a social parasite. Proceedings of the Royal Society $B$. Biological Sciences, 279(1728), 516-522. https://doi.org/10.1098/ rspb.2011.0581

Garnas, J. R., Drummond, F. A., \& Groden, E. (2007). Intercolony aggression within and among local populations of the invasive ant, Myrmica rubra (Hymenoptera: Formicidae), in Coastal Maine. Environmental Entomology, 36(1), 105-113. https://doi.org/10.1603/0046-2 25x(2007)36[105:iawaal]2.0.co;2

Ginzel, M. D., \& Blomquist, G. J. (2016). Insect hydrocarbons: Biochemistry and chemical ecology. In E. Cohen, \& B. Moussian (Eds.), Extracellular composite matrices in arthropods (pp. 221-252). Cham, Switzerland: Springer.

Giraud, T., Pedersen, J. S., \& Keller, L. (2002). Evolution of supercolonies: The Argentine ants of southern Europe. Proceedings of the National Academy of Sciences of the United States of America, 99(9), 6075-6079. https://doi.org/10.1073/pnas.092694199

GISD (Global Invasive Species Database) (2019). Retrieved from http:// www.issg.org/database
Goslee, S. C., \& Urban, D. L. (2007). The ecodist Package for dissimilarity-based analysis of ecological data. Journal of Statistical Software, 22(7), 1-19. https://doi.org/10.18637/jss.v022.i07

Gyllenstrand, N., Gertsch, P. J., \& Pamilo, P. (2002). Polymorphic microsatellite DNA markers in the ant Formica exsecta. Molecular Ecology Notes, 2(1), 67-69. https://doi.org/10.1046/j.1471-8286. 2002.00152.x

Gyllenstrand, N., Seppä, P., \& Pamilo, P. (2005). Restricted gene flow between two social forms in the ant Formica truncorum. Journal of Evolutionary Biology, 18(4), 978-984. https://doi. org/10.1111/j.1420-9101.2005.00908.x

Hakala, S. M., Seppä, P., Heikkilä, M., Punttila, P., Sorvari, J., \& Helanterä, H. (2018). Genetic analysis reveals Finnish Formica fennica populations do not form a separate genetic entity from F. exsecta. PeerJ, 6, e6013. https://doi.org/10.7717/peerj.6013

Hakala, S. M., Seppä, P., \& Helanterä, H. (2019). Evolution of dispersal in ants (Hymenoptera: Formicidae): A review on the dispersal strategies of sessile superorganisms. Myrmecological News, 29, 35-55. https:// doi.org/10.25849/myrmecol.news_029:035

Hamidi, R., de Biseau, J., Bourguignon, T., Martins Segundo, G. B., Fontenelle, M. T. M. B., \& Quinet, Y. (2017). Dispersal strategies in the highly polygynous ant Crematogaster (Orthocrema) pygmaea Forel (Formicidae: Myrmicinae). PLoS ONE, 12(6), 1-22.

Hamilton, W. D. (1964a). The genetical evolution of social behaviour I. Journal of Theoretical Biology, 7, 1-16.

Hamilton, W. D. (1964b). The genetical evolution of social behaviour II. Journal of Theoretical Biology, 7, 17-52.

Hasegawa, E., \& Imai, S. (2004). Characterization of microsatellite loci in red wood ants Formica (s. str.) spp. and the related genus Polyergus. Molecular Ecology Notes, 4(2), 200-203. https://doi. org/10.1111/j.1471-8286.2004.00614.x

Helanterä, H., Strassmann, J. E., Carrillo, J., \& Queller, D. C. (2009). Unicolonial ants: Where do they come from, what are they and where are they going? Trends in Ecology \& Evolution, 24(6), 341-349. https://doi.org/10.1016/j.tree.2009.01.013

Heller, N. E., Ingram, K. K., \& Gordon, D. M. (2008). Nest connectivity and colony structure in unicolonial Argentine ants. Insectes Sociaux, 55(4), 397-403. https://doi.org/10.1007/s00040-008-1019-0

Higashi, S., \& Yamauchi, K. (1979). Influence of a supercolonial ant Formica (Formica) yessensis Forel on the distribution of other ants in Ishikari coast. Japanese Journal of Ecology, 29(3), 257-264.

Hoffmann, B. D. (2014). Quantification of supercolonial traits in the yellow crazy ant, Anoplolepis gracilipes. Journal of Insect Science, 14(25), 1-21. https://doi.org/10.1673/031.014.25

Holway, D. A., Suarez, A. V., \& Case, T. J. (1998). Loss of intraspecific aggression in the success of a widespread invasive social insect. Science, 282(5390), 949-952.

Holzer, B., Chapuisat, M., Kremer, N., Finet, C., \& Keller, L. (2006). Unicoloniality, recognition and genetic differentiation in a native Formica ant. Journal of Evolutionary Biology, 19(6), 2031-2039. https://doi.org/10.1111/j.1420-9101.2006.01133.x

Holzer, B., Keller, L., \& Chapuisat, M. (2009). Genetic clusters and sex-biased gene flow in a unicolonial Formica ant. BMC Evolutionary Biology, 9(1), 69. https://doi.org/10.1186/1471-2148-9-69

Howard, R. W. (1993). Cuticular hydrocarbons and chemical communication. In D. W. Stanley-Samuelson, \& D. R. Nelson (Eds.), Insect lipids: Chemistry, biochemistry and biology (pp. 179-226). Lincoln, NE: Univ. Neb. Press.

Human, K., \& Gordon, D. M. (1996). Exploitation and interference competition between the invasive Argentine ant, Linepithema humile, and native ant species. Oecologia, 105(3), 405-412.

Kalinowski, S. T. (2011). The computer program STRUCTURE does not reliably identify the main genetic clusters within species: Simulations and implications for human population structure. Heredity, 106(4), 625-632. https://doi.org/10.1038/hdy.2010.95 
Katzerke, A., Neumann, P., Pirk, C. W. W., Bliss, P., \& Moritz, R. F. A. (2006). Seasonal nestmate recognition in the ant Formica exsecta. Behavioral Ecology and Sociobiology, 61(1), 143-150. https://doi. org/10.1007/s00265-006-0245-6

Kennedy, P., Uller, T., \& Helanterä, H. (2014). Are ant supercolonies crucibles of a new major transition in evolution? Journal of Evolutionary Biology, 27(9), 1784-1796. https://doi.org/10.1111/jeb.12434

Kidokoro-Kobayashi, M., Iwakura, M., Fujiwara-Tsujii, N., Fujiwara, S., Sakura, M., Sakamoto, H., Higashi, S., Hefetz, A., \& Ozaki, M. (2012). Chemical discrimination and aggressiveness via cuticular hydrocarbons in a supercolony-forming ant, Formica yessensis. PLoS ONE, 7(10), 1-14. https://doi.org/10.1371/journal.pone.0046840

Kümmerli, R., Gardner, A., West, S., \& Griffin, A. (2009). Limited dispersal, budding dispersal, and cooperation: An experimental study. Evolution, 63(4), 939-949. https://doi.org/10.1111/j.1558-5646.2008.00548.x

Kutter, H. (1969). Die sozialparasitischen Ameisen der Schweiz . Zürich, Switzerland: Naturforschenden Gesellschaft in Zürich.

Lester, P., \& Gruber, M. A. (2012). Comment on Moffett: "Supercolonies of billions in an invasive ant: What is a society?". Behavioral Ecology, 23(5), 934-935. https://doi.org/10.1093/beheco/ars047

Mabelis, A. (1979). The relationship between aggression and predation in the red wood ant (Formica polyctena Först.). Netherlands Journal of Zoology, 29(4), 451-620.

Mabelis, A. (1984). Aggression in wood ants (Formica polyctena Foerst., Hymenoptera, Formicidae). Aggressive Behavior, 10(1), 47-53.

Markó, B., Czekes, Z., Eros, K., Csata, E., \& Szász-Len, A. M. (2012). The largest polydomous system of Formica ants (Hymenoptera: Formicidae) in Europe discovered thus far in Romania. North-Western Journal of Zoology, 8(2), 287-291.

Martin, S. J., Helanterä, H., Kiss, K., Lee, Y. R., \& Drijfhout, F. P. (2009). Polygyny reduces rather than increases nestmate discrimination cue diversity in Formica exsecta ants. Insectes Sociaux, 56(4), 375-383. https://doi.org/10.1007/s00040-009-0035-z

Martin, S. J., Vitikainen, E., Drijfhout, F. P., \& Jackson, D. (2012). Conspecific ant aggression is correlated with chemical distance, but not with genetic or spatial distance. Behavior Genetics, 42(2), 323331. https://doi.org/10.1007/s10519-011-9503-0

Moffett, M. W. (2010). Adventures among ants. Berkeley, CA: University of California Press.

Moffett, M. W. (2012). Supercolonies of billions in an invasive ant: What is a society? Behavioral Ecology, 23(5), 925-933. https://doi. org/10.1093/beheco/ars043

Pamilo, P., \& Rosengren, R. (1984). Evolution of nesting strategies of ants: Genetic evidence from different population types of Formica ants. Biological Journal of the Linnean Society, 21(3), 331-348. https://doi. $\operatorname{org} / 10.1111 /$ j.1095-8312.1984.tb00370.x

Peakall, R., \& Smouse, P. E. (2012). GenAIEx 6.5: Genetic analysis in Excel. Population genetic software for teaching and research-an update. Bioinformatics, 28, 2537-2539.

Pedersen, J. S. (2012). The logic of hypersocial colonies. Behavioral Ecology, 23(5), 934-935. https://doi.org/10.1093/beheco/ars047

Pedersen, J. S., Krieger, M. J. B., Vogel, V., Giraud, T., \& Keller, L. (2006). Native supercolonies of unrelated individuals in the invasive argentine ant. Evolution, 60(4), 782-791. https://doi. org/10.1111/j.0014-3820.2006.tb01156.x

Pirk, C. W. W., Neumann, P., Moritz, R. F. A., \& Pamilo, P. (2001). Intranest relatedness and nestmate recognition in the meadow ant Formica pratensis (R.). Behavioral Ecology and Sociobiology, 49(5), 366-374. https://doi.org/10.1007/s002650000315

Pisarski, B. (1982). Influence de la structure sociale sur le comportement agressif des ouvrières de Formica (Coptoformica) exsecta. Memorabilia Zoologica, 38, 113-136.

Platt, T. G., \& Bever, J. D. (2009). Kin competition and the evolution of cooperation. Trends in Ecology \& Evolution, 24(7), 370-377. https:// doi.org/10.1016/j.tree.2009.02.009
Pohl, A., Ziemen, V., \& Witte, V. (2018). Mass occurrence and dominant behavior of the European ant species Formica fuscocinerea (Forel). Journal of Insect Behavior, 31(1), 12-28. https://doi.org/10.1007/ s10905-017-9654-9

Pritchard, J. K., Stephens, M., \& Donnelly, P. (2000). Inference of population structure using multilocus genotype data. Genetics, 155(2), 945-959.

Puechmaille, S. J. (2016). The program structure does not reliably recover the correct population structure when sampling is uneven: Subsampling and new estimators alleviate the problem. Molecular Ecology Resources, 16(3), 608-627. https://doi. org/10.1111/1755-0998.12512

QGIS Development Team (2018). QGIS Geographic Information System. Open Source Geospatial Foundation Project. Retrieved from http:// qgis.osgeo.org

Queller, D. C. (1992). Does population viscosity promote kin selection? Trends in Ecology \& Evolution, 7(10), 322-324. https://doi. org/10.1016/0169-5347(92)90120-Z

R Core Team (2013). A language and environment for statistical computing. Vienna Austria: R Foundation for Statistical Computing.

Raymond, M., \& Rousset, F. (1995). GENEPOP (Version 1.2): Population genetics software for exact tests and Ecumenicism. Journal of Heredity, 86(3), 248-249. https://doi.org/10.1093/oxfordjournals. jhered.a111573

Robinson, E. J. (2014). Polydomy: The organisation and adaptive function of complex nest systems in ants. Current Opinion in Insect Science, 5(1), 37-43. https://doi.org/10.1016/j.cois.2014.09.002

Rosengren, R., Cherix, D., \& Pamilo, P. (1986). Insular ecology of the red wood ant Formica truncorum Fabr. II. Distribution, reproductive strategy and competition. Mitteilungen Der Schweizerischen Entomologischen Gesellschaft, 59, 63-94.

Rosengren, R., \& Pamilo, P. (1983). The evolution of polygyny and polydomy in mound-building Formica ants. Acta Entomologica Fennica, 42, 65-77.

Rosengren, R., Sundström, L., \& Fortelius, W. (1993). Monogyny and polygyny in Formica ants: The result of alternative dispersal tactics. In L. Keller (Ed.), Queen number and sociality in insects (pp. 308-333). Oxford, UK: Oxford University Press.

Ross, K. G., Vargo, E. L., \& Keller, L. (1996). Social evolution in a new environment: The case of introduced fire ants. Proceedings of the National Academy of Sciences of the United States of America, 93(7), 3021-3025.

Roulston, T. H., Buczkowski, G., \& Silverman, J. (2003). Nestmate discrimination in ants: Effect of bioassay on aggressive behavior. Insectes Sociaux, 50(2), 151-159. https://doi.org/10.1007/s0004 0-003-0624-1

Rousset, F. (2008). GENEPOP'007: A complete re-implementation of the GENEPOP software for Windows and Linux. Molecular Ecology Resources, 8(1), 103-106. https://doi.org/10.1111/j.14718286.2007.01931.x

Savolainen, R., \& Vepsäläinen, K. (1988). A competition hierarchy among boreal ants: Impact on resource partitioning and community structure. Oikos, 51(2), 135-155.

Schultner, E., Gardner, A., Karhunen, M., \& Helanterä, H. (2014). Ant larvae as players in social conflict: Relatedness and individual identity mediate cannibalism intensity. American Naturalist, 184(6), E161-E174. https://doi.org/10.1086/678459

Schultner, E., Saramäki, J., \& Helanterä, H. (2016). Genetic structure of native ant supercolonies varies in space and time. Molecular Ecology, 25(24), 6196-6213. https://doi.org/10.1111/mec.13912

Schultz, R., \& Seifert, B. (2007). The distribution of the subgenus Coptoformica Müller, 1923 (Hymenoptera: Formicidae) in the Palaearctic Region. Myrmecological News, 10, 11-18.

Seifert, B. (2000). A taxonomic revision of the ant subgenus Coptoformica Mueller, 1923 (Hymenoptera, Formicidae). Zoosystema, 22(3), 517-568. 
Seppä, P., Gyllenstrand, N., Corander, J., \& Pamilo, P. (2004). Coexistence of the social types: Genetic population structure in the ant Formica exsecta. Evolution, 58(11), 2462-2471.

Seppä, P., Johansson, H., Gyllenstrand, N., Pálsson, S., \& Pamilo, P. (2012). Mosaic structure of native ant supercolonies. Molecular Ecology, 21(23), 5880-5891. https://doi.org/10.1111/mec.12070

Sorvari, J. (2009). Foraging distances and potentiality in forest pest insect control: An example with two candidate ants (Hymenoptera: Formicidae). Myrmecological News, 12, 211-215.

Sorvari, J., \& Hakkarainen, H. (2004). Habitat-related aggressive behaviour between neighbouring colonies of the polydomous wood ant Formica aquilonia. Animal Behavior, 67(1), 151-153. https://doi. org/10.1016/j.anbehav.2003.03.009

Sundström, L., Seppä, P., \& Pamilo, P. (2005). Genetic population structure and dispersal patterns in Formica ants - A review. Annales Zoologici Fennici, 42, 163-177.

Taylor, P. D. (1992). Altruism in viscous populations - An inclusive fitness model. Evolutionary Ecology, 6(4), 352-356.

Thomas, M. L., Payne-Makrisâ, C. M., Suarez, A. V., Tsutsui, N. D., \& Holway, D. A. (2007). Contact between supercolonies elevates aggression in Argentine ants. Insectes Sociaux, 54(3), 225-233.

Trontti, K., Tay, W. T., \& Sundström, L. (2003). Polymorphic microsatellite markers for the ant Plagiolepis pygmaea. Molecular Ecology Notes, 3(4), 575-577. https://doi.org/10.1046/j.1471-8286.2003.00516.x

Tsutsui, N. D., \& Case, T. J. (2001). Population genetics and colony structure of the Argentine ant (Linepithema humile) in its native and introduced ranges. Evolution, 55(5), 976-985.

Tsutsui, N. D., \& Suarez, A. V. (2003). The colony structure and population biology of invasive ants. Conservation Biology, 17(1), 48-58. https://doi.org/10.1046/j.1523-1739.2003.02018.x

Tsutsui, N. D., Suarez, A. V., Holway, D. A., \& Case, T. J. (2000). Reduced genetic variation and the success of an invasive species. Proceedings of the National Academy of Sciences of the United States of America, 97(11), 5948-5953.

van Wilgenburg, E., Torres, C. W., \& Tsutsui, N. D. (2010). The global expansion of a single ant supercolony. Evolutionary Applications, 3(2), 136-143. https://doi.org/10.1111/j.1752-4571.2009.00114.x
Vander Meer, R. K., \& Morel, L. (1998). In R. K. Vander Meer, M. Breed, M. Winston, \& K. E. Espelie (Eds.), Pheromone communication in social insects (pp. 79-103). Boulder, CO: Westview Press.

Vepsäläinen, K., \& Pisarski, B. (1982). Assembly of island ant communities. Annales Zoologici Fennici, 19(4), 327-335.

Vogel, V., Pedersen, J. S., D'Ettorre, P., Lehmann, L., \& Keller, L. (2009). Dynamics and genetic structure of argentine ant supercolonies in their native range. Evolution, 63(6), 1627-1639. https://doi. org/10.1111/j.1558-5646.2009.00628.x

West, S., Pen, I., \& Griffin, A. (2002). Cooperation and competition between relatives. Science, 296(5565), 72-75. https://doi.org/10.1126/ science.1065507

Wetterer, J. K., Wild, A. L. W., Suarez, A. V. S., Roura-Pscual, N. R., \& Espadaler, X. E. (2009). Worldwide spread of the Argentine ant, Linepithema humile (Hymenoptera: Formicidae). Myrmecological News, 12, 187-194.

Zinck, L., Hora, R. R., Châline, N., \& Jaisson, P. (2008). Low intraspecific aggression level in the polydomous and facultative polygynous ant Ectatomma tuberculatum. Entomologia Experimentalis et Applicata, 126(3), 211-216. https://doi.org/10.1111/j.1570-7458.2007.00654.x

\section{SUPPORTING INFORMATION}

Additional supporting information may be found online in the Supporting Information section.

How to cite this article: Hakala SM, Ittonen M, Seppä P, Helanterä H. Limited dispersal and an unexpected aggression pattern in a native supercolonial ant. Ecol Evol.

2020;10:3671-3685. https://doi.org/10.1002/ece3.6154 


\section{APPENDIX 1}

TABLE A1 Number of nests, area, and nest density for the studied subpopulations as well as separately for the four parts within the supercolony site

\begin{tabular}{|lllr|}
\hline Part & Nests & Area (ha) & nests/ha \\
\hline Supercolony site & 1,343 & 5.93 & 226.48 \\
\hline Part I & 281 & 1.11 & 253.78 \\
\hline Part II & 519 & 1.29 & 400.98 \\
\hline Part III & 519 & 1.87 & 277.66 \\
\hline Part IV & 24 & 0.09 & 275.76 \\
\hline Storsand & 16 & 0.63 & 25.26 \\
\hline Lillgård & 7 & 0.02 & 425.81 \\
\hline Storgård & 29 & 1.17 & 24.87 \\
\hline
\end{tabular}

Note: The area of the supercolony site is the area of all the open, and thus potentially habitable, parts of the field. The areas of the individual parts of the supercolony site and the smaller sites are defined as the polygon formed by drawing straight lines between the outermost nests.
TABLE A2 Pairwise comparisons between the factor levels of the fixed effects included in the models

\begin{tabular}{|c|c|c|c|}
\hline $\begin{array}{l}\text { Response } \\
\text { Pairwise comparisons }\end{array}$ & SE & $z$-Value & $p$ \\
\hline Presence of aggression & \multicolumn{3}{|c|}{ GLMM (binomial) } \\
\hline Neighbor-Distant & 0.401 & 2.231 & .026 \\
\hline Neighbor-Outside & 0.432 & 2.887 & .004 \\
\hline Neighbor-Allospecific & 0.729 & 6.709 & $<.001$ \\
\hline Distant-Outside & 0.406 & 0.866 & .386 \\
\hline Distant-Allospecific & 0.708 & 5.639 & $<.001$ \\
\hline Outside-Allospecific & 0.718 & 5.075 & $<.001$ \\
\hline Duration of aggression & \multicolumn{3}{|c|}{ GLMM (beta) } \\
\hline Neighbor-Distant & 0.317 & -0.290 & .772 \\
\hline Neighbor-Outside & 0.310 & -0.713 & .476 \\
\hline Neighbor-Allospecific & 0.299 & 1.111 & .267 \\
\hline Distant-Outside & 0.261 & -0.494 & .621 \\
\hline Distant-Allospecific & 0.238 & 1.780 & .075 \\
\hline Outside-Allospecific & 0.227 & 2.434 & .015 \\
\hline Duration of antennation & \multicolumn{3}{|c|}{ GLMM (beta) } \\
\hline Control-Neighbor & 0.195 & 5.454 & $<.001$ \\
\hline Control-Distant & 0.200 & 5.071 & $<.001$ \\
\hline Control-Outside & 0.336 & 3.737 & $<.001$ \\
\hline Neighbor-Distant & 0.210 & -0.231 & .818 \\
\hline Neighbor-Outside & 0.334 & 0.578 & .563 \\
\hline Distant-Outside & 0.343 & 0.703 & .482 \\
\hline
\end{tabular}

Note: Fixed effect levels: Control $=$ introduced ant from the same nest, Neighbor $=$ introduced ant from the same part of the supercolony field, Distant $=$ introduced ant from a different part from the supercolony field, Outside $=$ introduced ant from another field, Allospecific $=$ introduced ant of a different species, F. exsecta. The aggression models do not include the level "Control," for it had no aggression. The model for antennation does not include the level "Allospecific" due to it having aggression in all but three samples and thus too small a sample size for analyzing the nonaggressive behaviors. In all of the models, the nest IDs of both the host and the visitor were included as crossed random effects. 